\title{
Short Communication: Extraction of $\beta$-Casein from Goat Milk
}

\author{
S. Lamothe, G. Robitaille, D. St-Gelais, and M. Britten ${ }^{1}$ \\ Food Research and Development Centre, Agriculture, and Agri-Food Canada, Saint-Hyacinthe, Quebec, Canada J2S 8E3
}

\begin{abstract}
Peptides derived from milk $\beta$-casein have potential biological activities, such as antihypertensive and immunostimulating properties. These biological properties increase the demand for the production of specific bioactive peptides. $\beta$-Casein can be isolated directly from renneted skim milk, based on the preferential solubilization of $\beta$-casein at low temperature. This study was conducted to compare the recovery and purity of $\beta$-casein extracted from goat and cow milks. Rennet casein was prepared from both milks, heat treated, and dispersed in demineralized water at various temperatures. $\beta$-Casein recovery in the soluble phase increased with decreasing incubation temperature. Concentration of $\beta$-casein was $43 \%$ higher in goat milk than in cow milk, which had a direct effect on $\beta$-casein recovery. Furthermore, $\beta$-casein was extracted more efficiently from goat rennet casein. As a result, the extraction yield of $\beta$-casein was $53 \%$ higher in goat milk than in cow milk. The purity of $\beta$-casein extracted from both milks reached approximately $90 \%$ after incubation at $0^{\circ} \mathrm{C}$.
\end{abstract}

Key words: $\beta$-casein, goat, cow, milk

Casein is the main protein component of milk, constituting approximately $80 \%$ of the total milk protein fraction. Extensive research in vitro and on animal models has suggested that peptides derived from $\mathrm{CN}$ are not only nutrients, but also a source of low molecular weight peptides having potential biological activity. These peptides are generated and become active after digestion by proteolytic enzymes or during the fermentation and maturation processes of cheese and yoghurt (Korhonen and Pihlanto, 2006). Major CN-derived opioid peptides are fragments from bovine $\beta$-CN, called $\beta$-casomorphins because of their morphin-like behavior (Korhonen and Pihlanto, 2006). Antihypertensive and immunostimulating peptides can also be generated from bovine $\beta$ $\mathrm{CN}$ as well as from caprine $\beta$-CN (Minervini et al., 2003; Geerlings et al., 2006; Silva et al., 2006). These

Received June 27, 2007.

Accepted September 3, 2007.

${ }^{1}$ Corresponding author: brittenm@agr.gc.ca numerous biological activities increase the demand for fractionated and isolated $\mathrm{CN}$ as a source for the production of specific bioactive peptides. Molecular structures are important for peptide properties, and any variations in $\mathrm{AA}$ sequence and posttranslational modifications, such as phosphorylation or glycosylation, can affect bioactivity.

There are at least 19 polymorphic sites between caprine and bovine $\beta-\mathrm{CN}$ (GenBank database), and caprine $\beta$-CN possesses an additional phosphorylation site (Neveu et al., 2002). This opens the possibility of using $\mathrm{CN}$ originating from different species to generate new and modified bioactive peptides. For instance, the sequences of some antihypertensive casokinins from bovine $\beta$-CN (Silva et al., 2006) are modified or absent in caprine $\beta$-CN, and a casokinin identified in caprine $\beta$ $\mathrm{CN}$ was not found in the bovine counterpart (GómezRuiz et al., 2002). Further research is required to evaluate the biological activities of all these peptides and their potential as food supplements.

Several approaches have been proposed to produce high-quality food-grade $\beta$-CN. Microfiltration based on the selective solubility of $\beta$-CN at low temperature (Murphy and Fox, 1991; Van Hekken and Holsinger, 2000 ) is not suitable for the production of large quantities because of problems associated with low yield and temperature control during microfiltration. Recently, Huppertz et al. (2006) developed a large-scale procedure for the isolation of $\beta$-CN directly from renneted milk, based on the preferential solubilization of $\beta$-CN at low temperature. The purity of the $\beta$-CN fraction was greater than $80 \%$ and could be used without a further purification step. As a by-product, rennet curd can be used directly in food preparations, such as process cheese. The aim of this work was to prepare $\beta$-CN from cow and goat milks with this method to compare the recovery and purity of $\beta$-CN extracts obtained from both species.

$\beta$-Casein was extracted according to the experimental procedure proposed by Huppertz et al. (2006). Bulk cow (Parmalat, St-Hyacinthe, Quebec, Canada) and goat (Laiterie Tournevent, Drummondville, Quebec, Canada) milks were skimmed, pasteurized at $65^{\circ} \mathrm{C}$ for 30 min, and cooled to $30^{\circ} \mathrm{C}$. For both milks, $\mathrm{pH}$ was adjusted to 6.4 with $1 \mathrm{~N} \mathrm{HCl}$, and milk was allowed to 
Table 1. Protein composition of cow and goat skim milks

\begin{tabular}{lrr}
\hline Item & \multicolumn{1}{c}{ Cow } & \multicolumn{1}{c}{ Goat } \\
\hline Total protein, \% & $3.36 \pm 0.05$ & $3.34 \pm 0.03$ \\
CN, \% & $2.63 \pm 0.05^{\mathrm{a}}$ & $2.52 \pm 0.03^{\mathrm{b}}$ \\
$\kappa$-CN, \% & $10.90 \pm 0.25^{\mathrm{a}}$ & $9.02 \pm 0.53^{\mathrm{b}}$ \\
$\alpha_{\mathrm{s} 2}$-CN, \% & $7.51 \pm 0.20^{\mathrm{b}}$ & $20.93 \pm 0.91^{\mathrm{a}}$ \\
$\alpha_{\mathrm{s} 1^{-}} \mathrm{CN}, \%$ & $47.25 \pm 0.79^{\mathrm{a}}$ & $18.89 \pm 0.70^{\mathrm{b}}$ \\
$\beta$-CN, \% & $34.34 \pm 0.37^{\mathrm{b}}$ & $51.16 \pm 0.12^{\mathrm{a}}$ \\
\hline
\end{tabular}

${ }^{\mathrm{a}, \mathrm{b}}$ Means within a row with different superscripts are different $(P$ $<0.05)$.

equilibrate for $1 \mathrm{~h}$ at $30^{\circ} \mathrm{C}$. Rennet (double-strength rennet, Maxiren, Chr. Hansen's Laboratory, Ontario, Canada) and $\mathrm{CaCl}_{2}$ (Sigma, St. Louis, MO) stock solution $(32 \% \mathrm{wt} / \mathrm{wt})$ were added to milk $(1 \mathrm{~L})$ at respective concentrations of 0.1 and $0.26 \mathrm{~mL} / \mathrm{L}$. Milk was held at $30^{\circ} \mathrm{C}$ for 15 min under low agitation, allowing $\mathrm{CN}$ precipitation. This was followed by $15 \mathrm{~min}$ of incubation at $30^{\circ} \mathrm{C}$ without agitation to increase the particle size. The precipitate was filtered through Whatman no. 40 filter paper, dispersed in demineralized water at $70^{\circ} \mathrm{C}$, and held at this temperature for $5 \mathrm{~min}$ to inactivate the chymosin. The mixture was filtered and the supernatant was discarded. The precipitate was minced with a 500-mL food processor (Mini-Prep Plus, DLC-2A model, Cuisinart, East Windsor, NJ) for 1 min at maximum speed, suspended in demineralized water (at $30^{\circ} \mathrm{C}$ ) to a volume corresponding to half of the original milk sample, and separated into 4 equal parts. The suspensions were held at $0,4,8$, and $16^{\circ} \mathrm{C}$ for $16 \mathrm{~h}$. The supernatants were filtered through Whatman no. 40 filter paper. Total nitrogen, non-CN nitrogen, and NPN were determined according to International Dairy Federation standard methods (1993) and used for CN determination in the original skim milks and supernatants. Relative proportions of each CN fraction in milk and in the supernatants were assessed by HPLC (Jaubert and Martin, 1992). The proportion of $\beta$-CN over total $\mathrm{CN}$ in the supernatants was taken as the purity of the extract. To determine the recovery of $\beta$-CN, the concentration of $\beta$-CN in the supernatant after incubation (corrected for the volume that corresponded to half of the original milk sample) was divided by the $\beta$-CN content of the original milk and expressed as a percentage. The preparation of bovine and caprine rennet $\mathrm{CN}$ and the solubilization of $\beta$-CN at various temperatures was repeated 3 times. Compositional data on the original milks and $\beta$-CN extracts were subjected to ANOVA (SAS Institute Inc., Cary, NC).

Table 1 presents the protein composition of original cow and goat skim milks. The CN content was slightly higher in cow skim milk $(P<0.05)$. The relative amount of the individual $\mathrm{CN}$ in goat and cow milks reported here was consistent with previous studies (Farrell et

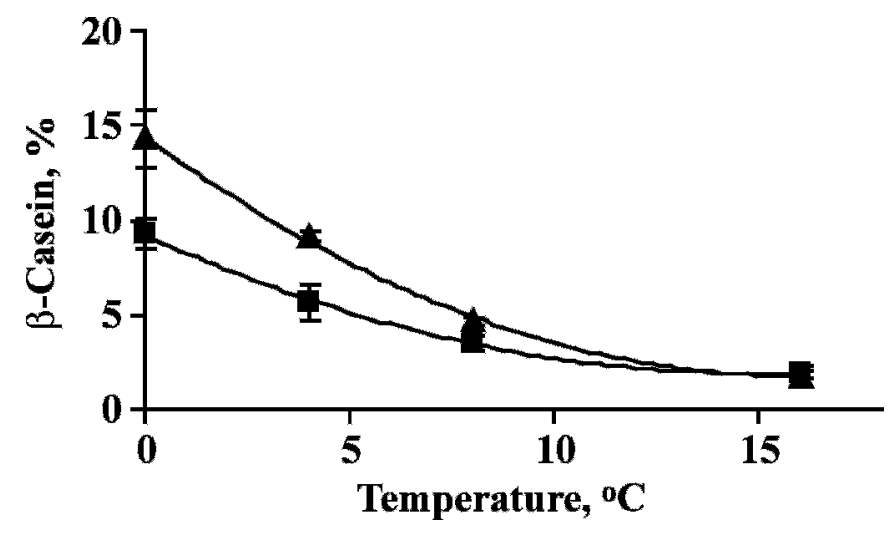

Figure 1. Influence of incubation temperature on $\beta$-CN recovery from cow (ם) and goat ( $\mathbf{\Delta})$ milk.

al., 2004; St-Gelais et al., 2005). $\beta$-Casein represented the major protein component of goat milk. The concentration of $\beta$-CN in goat milk was $43 \%$ higher than in cow milk.

The effect of temperature on $\beta$-CN recovery in cow and caprine extracts is shown in Figure 1. Milk origin and rennet $\mathrm{CN}$ incubation temperature had significant effects on $\beta$-CN yield $(P<0.0001)$. $\beta$-Casein recovery in cow and goat extracts increased up to 5- and 8-fold, respectively, as the incubation temperature decreased from 16 to $0^{\circ} \mathrm{C}$.

The total amount of $\beta$-CN obtained at $0^{\circ} \mathrm{C}$ was 2 times higher for goat milk, with a production of $0.185 \mathrm{~g}$ of $\beta$ $\mathrm{CN} / 100 \mathrm{~mL}$ of milk, compared with $0.083 \mathrm{~g} / 100 \mathrm{~mL}$ of milk for cow milk. This shows the efficiency of the method applied to goat milk. The difference in the amounts recovered can be explained by a greater concentration of $\beta$-CN in the $\mathrm{CN}$ fraction of goat milk, by the higher solubility of caprine $\beta$-CN at low temperature (O'Conner and Fox, 1973; Raynal and Remeuf,

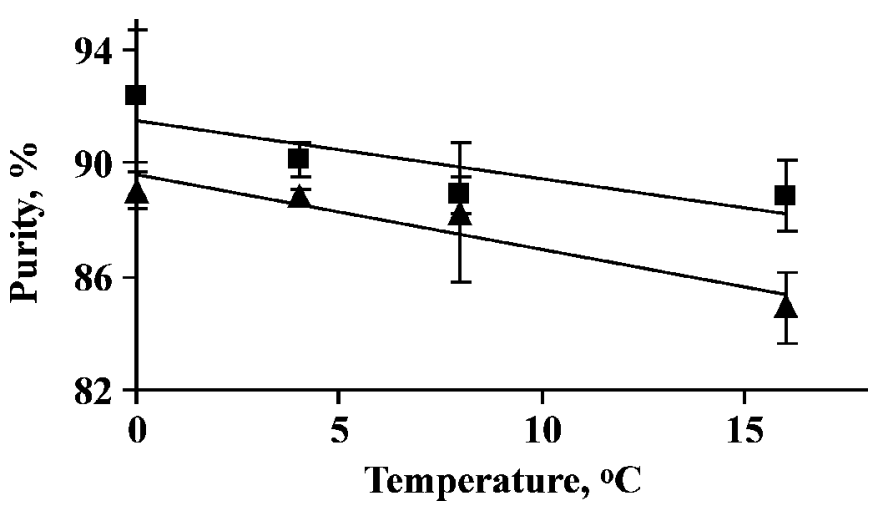

Figure 2. Influence of incubation temperature on the purity of $\beta$ -

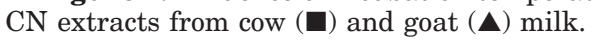




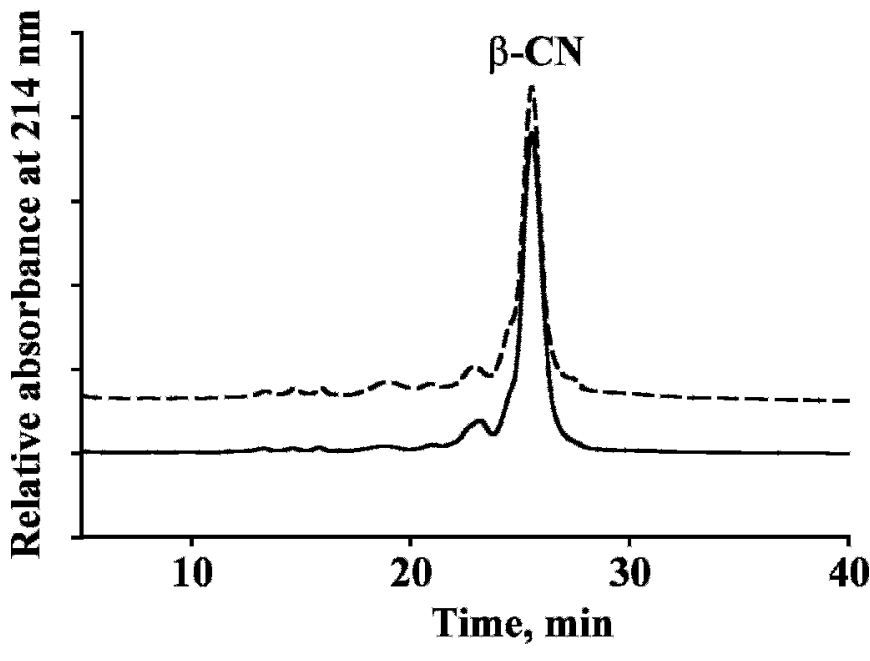

Figure 3. High-performance liquid chromatographic profiles of $\beta$ $\mathrm{CN}$ extracted from renneted goat skim milk at 0 (-) and $16^{\circ} \mathrm{C}$ (-------).

2002), and by the weaker curds made from goat milk compared with those from cow milk (Ambrosoli et al., 1988), which may enhance $\beta$-CN diffusion in the medium.

In the present work, $\beta$-CN recovery from cow milk was about half the value reported by Huppertz et al. (2006) for similar conditions. The difference could be attributed to the method used to break the curd. As mentioned by Huppertz et al. (2006), the dissociation of $\beta$-CN is hindered by the curd matrix. To improve $\beta$-CN dissociation, they used a mortar and pestle to pulverize the curd particles and increase the surface area, thus facilitating $\beta$-CN diffusion in the medium. In the present study, a food processor was used to chop the precipitate, which resulted in larger particles and, as a consequence, decreased the extraction yield. Increasing the incubation time to $24 \mathrm{~h}$ and performing a second extraction at $0^{\circ} \mathrm{C}$ could be considered to improve the yield. The use of a colloidal mill might be an option to decrease particle size further and could be more appropriate for the large-scale isolation of $\beta$-CN.

As shown in Figure 2, the purity of $\beta$-CN was slightly higher in cow extracts than in goat extracts $(P<0.05)$. The purity significantly decreased when the incubation temperature was raised $(P<0.0001)$, probably because of a higher residual plasmin activity, which is responsible for CN degradation (Bastian and Brown, 1996; Trujillo et al., 1997). High-performance liquid chromatog- raphy analysis of the supernatants clearly showed that the proportion of impurities increased with increasing incubation temperature (Figure 3). Results presented in this communication showed a high extraction yield of caprine $\beta$-CN by solubilization of $\beta$-CN from rennet $\mathrm{CN}$ at low temperature.

\section{REFERENCES}

Ambrosoli, R., L. di Stasio, and P. Mazzocco. 1988. Content of $\alpha_{\mathrm{s} 1^{-}}$ casein and coagulation properties in goat milk. J. Dairy Sci. $71: 24-28$.

Bastian, E. D., and R. J. Brown. 1996. Plasmin in milk and dairy products: An update. Int. Dairy J. 6:435-457.

Farrell, H. M., Jr., R. Jimenez-Flores, G. T. Bleck, E. M. Brown, J. E. Butler, L. K. Creamer, C. L. Hicks, C. M. Hollar, K. F. NgKwai-Hang, and H. E. Swaisgood. 2004. Nomenclature of the proteins of cows' milk-Sixth revision. J. Dairy Sci. 87:1641-1674.

Geerlings, A., I. C. Villar, F. Hidalgo Zarco, M. Sanchez, R. Vera, A. Zafra Gomez, J. Boza, and J. Duarte. 2006. Identification and characterization of novel angiotensin-converting enzyme inhibitors obtained from goat milk. J. Dairy Sci. 89:3326-3335.

Gómez-Ruiz, J. A., M. Ramos, and I. Recio. 2002. Angiotensin-converting enzyme-inhibitory peptides in Manchego cheeses manufactured with different starter cultures. Int. Dairy J. 12:697-706.

Huppertz, T., J. B. Hennebel, T. Considine, S. U. Rehman, A. L. Kelly, and P. F. Fox. 2006. A method for large-scale isolation of $\beta$-casein. Food Chem. 99:45-50.

International Dairy Federation. 1993. Nitrogen content of milk and milk products. IDF Standard No. 20B. Int. Dairy Fed., Brussels, Belgium.

Jaubert, A., and P. Martin. 1992. Reverse-phase HPLC analysis of goat caseins. Identification of $\alpha_{\mathrm{s} 1}$ and $\alpha_{\mathrm{s} 2}$ genetic variants. Lait 72:235-247.

Korhonen, H., and A. Pihlanto. 2006. Bioactive peptides: Production and functionality. Int. Dairy J. 16:945-960.

Minervini, F., F. Algaron, C. G. Rizzello, P. F. Fox, V. Monnet, and M. Gobbetti. 2003. Angiotensin I-converting-enzyme-inhibitory and antibacterial peptides from Lactobacillus helveticus PR4 proteinase-hydrolyzed caseins of milk from six species. Appl. Environ. Microbiol. 69:5297-5305.

Murphy, J. M., and P. F. Fox. 1991. Fractionation of sodium caseinate by ultrafiltration. Food Chem. 39:27-38.

Neveu, C., D. Mollé, J. Moreno, P. Martin, and J. Léonill. 2002. Heterogeneity of caprine beta-casein elucidated by RP-HPLC/MS: Genetic variants and phosphorylations. J. Prot. Chem. 21:557567.

O'Conner, P., and P. F. Fox. 1973. Temperature-dependent dissociation of casein micelles from the milk of various species. Neth. Milk Dairy J. 27:199-217.

Raynal, K., and F. Remeuf. 2002. Effect of storage at $4^{\circ} \mathrm{C}$ on the physicochemical and renneting properties of milk: A comparison of caprine, ovine and bovine milks. J. Dairy Res. 67:199-207.

Silva, S. V., A. Pihlanto, and F. X. Malcata. 2006. Bioactive peptides in ovine and caprine cheeselike systems prepared with proteases from Cynara cardunculus. J. Dairy Sci. 89:3336-3344.

St-Gelais, D., S. Turcot, and A. Ould Baba Ali. 2005. Chemical composition and properties of milk from five goat breeds. Milchwissenschaft 60:140-143.

Trujillo, A. J., B. Guamis, and C. Carretero. 1997. Hydrolysis of caprine $\beta$-casein by plasmin. J. Dairy Sci. 80:2258-2263.

Van Hekken, D. L., and V. H. Holsinger. 2000. Use of cold microfiltration to produce unique $\beta$-casein enriched milk gels. Lait 80:69-76. 